\title{
Conflict of Interest in Institutional Arrangement and Apparatus Placement Resource of Regional Expansion in Indonesia
}

\author{
Suraji (Corresponding Author) \\ Lecturer, of Hangtuah University Surabaya Indonesia \\ Ph.D Student, Ghazali Shafie Graduate School of Government \\ Universiti Utara Malaysia, Malaysia \\ E-mail: surajimunawir@gmail.com \\ Muhammad Ali Embi \\ Professor, College of Law, Government and International Studies \\ Universiti Utara Malaysia, Malaysia \\ E-mail: ali@uum.edu.my
}

Received: Nov. 20, 2017 Accepted: Dec. 6, 2017 Online published: Dec. 8, 2017

doi:10.5296/jpag.v7i4.12260 URL: https://doi.org/10.5296/jpag.v7i4.12260

\begin{abstract}
This study aims to describe, analyze and assess exhaustively the implementation of institutional arrangement and the placement of local apparatus resources in the expansion area as well as the conflict of interest in the arrangement of regional institutions and placement of local apparatus resources and settlement of conflict of interest in regional institutions arrangement and the placement of local apparatus resources in the expansion area Pangandaran District. This study applies case study approach as qualitative method by interviewing eight participants (see Appendix 1) that are involved in regional expansion from various occupations. The gap of this study is the existence of the conflict of interest in the institutional arrangement and apparatus placement resource in the new regional expansion. This study found that there is a conflict association that caused the lack of development in regional expansion. The resolutions were as follows: (a) Establishment of a joint forum on a regular basis between the regent, council presidium and community leaders to discuss the plan and program areas. (B) The Regent accommodates the council presidium proposal, and
\end{abstract}


put the appropriate and qualified officials. (C) Improve the performance of the region and increase cooperation in order to avoid misunderstanding by the local governments. Theoretically, this study is hoped could strengthen the conflict theory in the new district of regional expansion. On the other hand, the government's role is hoped in arranging and managing the institution as well as apparatus resource in regional expansion by inventing the laws and policies to execute it.

Keywords: conflict of interest, institutional, apparatus resources, regional expansion, Indonesia

\section{Introduction}

Basically, the policy of regional expansion was a new concept in Indonesian regional autonomy policy that was capable to deliver the best services to the welfare of society. This is due to the high demand policy regarding the regional expansion in Java and outside Java that triggered the demands on the expansion itself with several reasons among others: Firstly, the motives of governmental administration effectiveness/efficiency are recalling the regional region that was so wide, has prevalent population but a left behind development. Secondly, the trends of homogeneity (ethnic, language, religion, urban-rural, income level, and etc.). Thirdly, the existence of fiscal spoilt that was guaranteed by the laws (provided public allocation fund/DAU, profit share from natural resources and the availability of Regional Income Source (PAD). And lastly, the rent-seeking motive from the elites (Fitriani et al., 2005).

Due to the policy, the development of regency/city nowadays and the total provinces in Indonesia can be seen in the following table:

Table 1. The Development of Regional Expansion in Indonesia (1999-2017)

\begin{tabular}{cccc}
\hline The Number of Regional & $\mathbf{1 9 9 9}$ & Improvement Rate & $\mathbf{2 0 1 6}$ \\
Autonomy & 26 & 8 & 34 \\
Province & 234 & 186 & 420 \\
Regency & 59 & 35 & 94 \\
City & 319 & 205 & 548 \\
\hline
\end{tabular}

Source: The Ministry of Internal Affairs (2017)

Based on the above table, it can be seen that moderately during 16 years there are 20 new autonomy regions have been emerged every year, namely: out of 34 provinces, there are 8 improvement rates from 26 provinces $(27.9 \%)$ and in terms of regency/city government out of 420 provinces, there are 186 improvement rates from 234 provinces $(65.2 \%)$.

After the expansion policy implemented several studies, it was concluded that the implementation of regional extension had failed. This was due to the regional expansion implementation have not responded the issue of public welfare and service improvement. The expansion was conducted without a proper planning, religious, ethnical based, subjective and also an instant elite interest to share power and public positions (Sudi Fahmi, 2009).

According to Eko Prasojo (2012), the expansion issues were not only dominated by political 
interest, but also due to the central government's inconsistency in applying rules on the expansion. Furthermore, Eko Prasojo said that the discussion of regional expansion and new regional forming, the subjectivity elements that are more dominant than primordialism elements, political party, local and national elite interest are tend to utilize that conditions for the sake of getting more votes in public election.

The issues of regional expansion that took place in Indonesia generally showed the following problems:

1. The regional apparatus resource quality was far from the expectation both from educational aspect, experience, performance standards, regulation understanding and also the managers' and employees' placement were not compatible with their competences.

2. The limits of regional expansion in formulating vision and mission, institutional main tasks and conducting the regional institutional wheels were very minimum.

3. The regional readiness in implementing the autonomy actually showed the trends of mostly the lack of performance of regional expansion and also the emergence of corruption in the regional expansions. (The Ministry of Internal Affairs, 2017)

Apart from those factors, the problems in regional expansion were the emergence of elite and public interest conflicts in the implementation to be a new autonomy region. The facts have showed that regional extension policy took place in most of Indonesian provinces whereby those were not separable from the conflicts as the following table:

Table 2. Conflict of Indonesian Regional Expansion Process

\begin{tabular}{lll}
\hline $\begin{array}{l}\text { Province/ } \\
\text { Regency/City }\end{array}$ & Conflicts Occurred & $\begin{array}{l}\text { Extension } \\
\text { year }\end{array}$ \\
\hline Nunukan Regency & Bulungan Regency & 1999 \\
Singkawang City & Bengkayang Regency & 1999 \\
Lampung Regency & Metro City & 2000 \\
Lhoksukon Regency & Lhoksumawe City & 2001 \\
Kepulauan Riau Province & Pros Counter Discussion & 2002 \\
Papua Barat Province & Pros Counter Discussion & 2002 \\
Batu Barat Sumut Province & Pros Counter Discussion & 2002 \\
Tapanuli Province & Pros Counter Discussion & 2003 \\
Kampar Regency & The seizure of three villages with the Regions & 2004 \\
Ogan Regency & Ogan Regency & 2005 \\
Natuna Regency & The battle for Anambas territory & 2006 \\
Lampung Selatan Regency & Pesawaran Regency & 2007 \\
Sorong Selatan Papua & Maybart Regency Papua Barat & 2007 \\
Sumbawa Regency & Seizing of the Sumbat Tribe & 2007 \\
Konawe Regency & Konawe Regency & 2008 \\
Daerah Hulu Sungai Utara & Grabbing the Balangan Stag & 2009 \\
Banjar City Jabar & Ciamis Regency & 2010 \\
Papua Barat Manukwari & Teluk Bintuni Regency & 2002 \\
Musi Rawas Regency & Lubuk Linggau City & 2009 \\
Daerah Ciamis & Banjar Regency & 2010 \\
Malang City & Batu Regency & 2011 \\
Moro Wali Regency & Morowali Regency & 2013 \\
Musi Waras Regency & Musi Waras Utara Regency & 2014 \\
\hline
\end{tabular}


Source: The Ministry of Internal Affairs (2017)

The above data has showed that several provinces and regencies/cities of expansion process were not separable from the conflicts. There were various conflicts that occurred among regions. For instance, asset seizure conflict that happened in capital regency (Nunukan Regency), population-migration conflict (Sengkawang City), APBD conflict (Lampung Province), pros and cons conflict of expansion (Riau Island, West Papua, Batu regency of North Sumatra, Tapanuli Province), Ethnic, Religion and Race conflict (Polewali Mamasa Regency), conflict of mining natural wealth seizure (Sumbawa Regency), conflict of tourism location seizure (Batu City). The conflicts of expansion above have showed that the interest occurred between pros and cons supporters as well as the interest conflicts with capital regency with various backgrounds such as region seizure, natural resources seizure, tourism location, population-migration as well as race or religion conflicts (The Ministry of Internal Affairs, 2017).

In terms of management of institution and placement of apparatus resources, the regional expansion had referred to Regulation No.23/2004 on Regional Government (amended Regulation No32/2014), Governmental Regulation (PP) number 78 of 2007 on procedures of forming, deletion, regional incorporation and Regulation number 43 in 1999 on State Civil Apparatus (later amended Regulation no.5/2014). The principle was a reference in the implementation of regional expansion and a placement of regional apparatus that emphasized competences, qualifications, performances, transparencies, objective principles and freedom in political interventions and Corruption, Collusion and Nepotism (KKN). However, whatever happened the model has triggered the interest conflicts. The facts have showed that regional expansion policy took place in almost all Indonesian provinces whereby it was not separable from interest conflicts in institutional management and placement of regional apparatus resources. It can be seen as the following table below:

Table 3. Scopes of Conflicts in Regional Expansion (Regencies/Cities)

\begin{tabular}{ccc}
\hline Capital Region & Extension Region & Year \\
\hline West Papua Manukwari & Teluk Bintuni Regency & 2002 \\
Musi Rawas Regency & Lubuk Linggau City & 2009 \\
Tasikmalaya Regency & Tasikmalaya City & 2009 \\
Kerinci Regency & Sungai Penuh City & 2009 \\
Ciamis Regency & Banjar Regency & 2010 \\
Malang City & Batu Regency & 2011 \\
Ciamis Regency & Pangandaran Regency & 2012 \\
\hline
\end{tabular}

Source: The Ministry of Internal Affairs (2017)

The table above has showed that there were several regencies/cities occurred the conflict in the implementation of regional expansion. For instance, the determination and placement of SKPD position (Bintuni Bay), interest of official movement and regulation incompliance in position determination (Lubuk Linggau Ciity), and capital regional apparatus that were not wanted to be moved in the regional expansion (Tasikmalaya City), educational issues, funds, family matters, conflict of educations and training delivery participants, involvement in initial expansion and also position interest (Sungai Penuh City, Banjar Rehency, Batu Regency). In 
addition, conflicts of interest of institutional management, placement and determination of Regent position, Regional Secretary (SEKDA), SKPD determination, and regional apparatus placement were the conflicts within extension presidium (Pangandaran Regency).

In that context, the above issues generally have showed that institutional management and regional apparatus resource placement that referred to the existing regulations have emerged interest conflicts in the regional expansion as well as the regional non-readiness in managing an autonomy region. The conflict of interest in institutional management and regional apparatus resource placement became a crucial factor to be discussed in this research. This discussion was expected to resolve the problems and give a proper solution that is suitable with the state administration discussion among others on regional expansion policy, regional autonomy, bureaucracy, governmental performance, institution, leadership, apparatus resources, conflict solution and the improvement of regional public services.

This research was different with the research discussion that was conducted by the previous experts and the academicians. This research focused on the conflict of interest in the institutional management and regional apparatus resource placement in the regional expansion. In the existing dynamics have showed that the expansion was full of interest both official, political parties, public figures and national interests. The objective of an expansion was to approach and to deliver an optimum public service. However, the process of becoming an autonomy region was inseparable of the conflict of interest. Hence, the regional expansion that resulted in conflicts should return according to regulations that available. This research focused on the institutional management and regional apparatus placement and conflict of interest of institutional main tasks of formulation, structure, organization, determination of Regional Government/SKPD organizational staffing, determination of Regent Position, Sekda, SKPD, determination of SKPD structure position, and placement of regional apparatus employees.

\section{Conceptual Study}

The conceptual study was initiated by a decentralized concept according to Smith (1985) whereby it was a political phenomenon that involved administration and government. Decentralization was an authorization whereby it delegates to a lower level power region whether one of governmental hierarchies in the state government or similar offices in a large organization, while in general, decentralization was divided into two types namely: territorial decentralization and functional decentralization. Functional decentralization meant an authorization that transfers to a functional organization (technical) that directly related to public Rondinelli and Cheema (1983) stated that decentralization was a delegation of specific functional responsibilities to organization outside of governmental bureaucracy structure and it was indirectly controlled by Central Government.

The problem of a power relation between central government and regional government in the united states is it consolidated in national governmental level. Therefore, the power in regional government is really depend on the national government pleasure to decentralize. According to Daniel J. Elazar (1995), decentralization was not an independent system, but a series of a unity of a bigger system. Miftah (2015) said that decentralization was national 
governmental interest that form a nationalism spirit that was not narrowed by regional sectarian spirit. The understanding was delivered a confirmation that decentralization was a general regional demand. This was called an extension as an effort of delivering authority to the region to be an autonomy region.

\subsection{Concept of Regional Expansion}

The regional expansion according to Gabrielle Ferrazzi (2007), could be viewed as a part of regional management process or territorial reform or administration reform i.e. a management in a size and also a hierarchy in regional government to achieve goals, both in political and administrative objectives. The regional management generally covered the regional expansion, incorporation and eradication. Likewise, he highlighted that the main strategy of an optimum regional expansion does not only determine the number of ideal autonomy regions in a state, but more than that it should be able to answer the question of what actually the function of a regional autonomy was. After that, we look for the answer of what the objectives of a regional expansion, specifically in the context of territorial reform (Gabriele Ferrazzi, 2007).

According to Kosworo (2001), a regional expansion was an implementation of decentralized principles, precisely it was a territorial decentralization. A territorial decentralization was an authority that was given by the government to a public board such as an alignment with a self-government to develop the whole interrelated interest from groups of population in a specific region.

Constitution in 1945 did not constitute a regional forming or a regional expansion specifically, but it was mentioned in Article 18 B verse (1) that "A state acknowledges and respects regional governmental units that was specific in nature or extraordinary in nature that was governed by regulations". Further, in verse (2) the same article mentioned the following phrases:"A state acknowledges and respects the custom law community units along with their traditional rights as long as it still alive and suitable with the community development and principles of United States of Republic Indonesia that was governed in the regulations".

More specifically, Regulation Number 32 in 2004 (amended Regulation 23/2014) that constituted the provisions on regional forming in Chapter II and Specific Territory. This could be analogized that a regional expansion was also included in a regional forming coverage. Regulation Number 32 in 2004 determined that a regional forming should be determined by a specific regulation. This provision was mentioned in Article 4 verse (1). Later, in verse (2) the same article was mentioned as followed, "the regulations of a regional forming as mentioned in verse (1) among others were covered name, regional coverage, limits, capital, authority to establish a governmental affair, appointment of regional chief officer, Regional House of Representative (DPRD) staffing, staffing transfer, funding, equipment, document and also regional apparatus". The legalization of a regional expansion was mentioned in the same articles in the following verse (verse 3 ) that stated, "regional forming could be in form of several regional incorporations or part of adjacent regions or a regional expansion that became two or more regions". And verse (4) stated, "then extension of a region became 2 (two) regions or more as mentioned in verse (3) that it could be conducted after achieving 
minimal limit of a governmental establishment". However, regional forming could only be conducted if it had fulfilled administrative, technical and physical requirements of regions. In terms of provinces, the administrative requirements were obliged to fulfill cover regency/city DPRD approval and regent/governor would be the coverage towards province of related regions, approval of capital province DPRD and Governor and also the Ministry of Internal Affair recommendation.

Meanwhile, in terms of regency/city, the administrative requirements should be fulfilled to cover regency/city DPRD approval, regent/governor related, province DPRD approval and also the governor as well as the Ministry of Internal Affair recommendation. Furthermore, technical requirements from new regional forming should cover actors who were the principals of regional forming that cover the following factors: a) economic ability, b) regional potentials, c) social culture, d) social politics, e) population, f) regional width, g) defense, h) safety, i) and other factors that enable regional autonomy implementation.

On the other hand, according to PP Number 78 in 2007 on management of Regional Forming and incorporation that was mentioned as a regional expansion was a province or regency/city that splitting into two regions or more. Regional expansion of regency/city became several new regency/city regions was basically an effort to improve service quality and intensity to public. Regional expansion was principally also an effort to improve public welfare by improving and speeding up services and improving a democratic political life, regional economic, regional potential management, safety and orders and also a harmonious relation between central and regional.

The regional expansion context was synergized by a regional decentralization and autonomy that were a reform demand and regional needs. However, its implementation was not proportional with the expectation at which it was the objectives of an extension policy. According to Tryatmoko (2010), governability local issue was not only marked by weakness or extension of a regional expansion results, but also a public ability weakness in supporting local political and economic development. Furthermore, Tryatmoko then highlighted the issue of governmental policy effectiveness in governing cover public involvement in decision making and also control governmental run. In this case, regional expansion needed to pay attention and continuously controls and evaluates the implementation step by step.

\subsection{Concepts of Institutional and Apparatus Management}

One of important factors of unsuccessful regional expansion became a new autonomy was institutional management in running service tasks as well as regional development. The concept that could be reviewed in answering expansion issues were among others of institutional capacity concept. The institutional capacity was a strategic approach in development plans in materializing a good governance based on: (1) capacity in implementing policies and governmental functions, (2) accountability and transparency in decision making, (3) participation in a democracy process, (4) care of poverty and welfare equalization, (5) commitment towards a market-oriented economic policy.

To respond the readiness of the regional expansion to be an autonomy region could be 
referred from Keban (2000) opinion that stated as the attempts to strengthen the ability of regency and city region both as an institution as well as an apparatus individual could refer to the ability development that covered: (1) composing strategic planning and policy formulation; (2) organizational design; (3) management approach; (4) moral and work ethic and (5) accountability. Meanwhile, the individual development covered: (1) ability to perform jobs' compatibility with job's needs; (2) ability to face the future; (3) guidance of the job's motive that suitable with the job's needs; (4) personality guidance at work.

The concept was in line with Grindle's (2007) opinion in which it stated that an institutional capacity was an effort that aimed to develop a strategy variation in order to improve efficiency, effectiveness and responsiveness in a governmental performance namely: efficiency in time and resources that were needed to achieve an objective; effectiveness in form of business feasibility that conducted for the desired results; and responsiveness referred to how to synchronize the needs and ability to achieve the objectives. In this subject, Grindle (1997) stated that an institutional capacity had activity dimensions, focus and types among others such as: (1) human resources development dimension that focused on professional personnel and technical ability and also activities such as training, direct practice, work condition and recruitment; (2) organizational strengthening dimension that focused on the management to improve successfully the roles and functions and also activity types such as incentive system and personnel equipment and (3) institutional reform dimension that focused on institution and system and also macro structure with activity types such as economic political rules, policy and regulation of change and also constitutional reform.

\subsection{Concepts of Conflict of Interest}

According to Webter (1966), the term "conflict" in its original language meant a "fight, war or struggle" in form of physical confrontation among several parties. However, the meaning of the word then develops along with the entrance of "sharp dissent or opposition on various interest, idea and so forth". On the other hand, the term nowadays also touched a psychological aspect behind a physical confrontation that occurred besides physical confrontation itself. Shortly, the term "conflict" became wider so that it was too risky to loose status as a single concept. In the context of interest according to Surbakti (1992), the interest group was a number of people who have similarities in nature, attitude, self-confidence or objectives that agree to organize themselves in order to guide them in achieving the objectives. Meanwhile, Farazmand Almmond (2001) stated that the interest groups are those organizations that attempted to influence governmental policy without, at the same time, desired to obtain a public position.

The above conflict classification can be viewed from the number of people and group facets who interact then occurred dispute. This could be observed in our living environment and wider environment. However, we need to contemplate whether each conflict was something good or a disruption. About this case, there were two aspects that we could contemplate. Firstly, a conflict was an indication of something wrong or a problem that needed to be determined. Secondly, a conflict created a widening undermine consequences. In general, conflict would occur anywhere as long as there happened interaction or relation among 
humans both individual with individual as well as group to group in doing something. In its development, conflicts related to a strategic position that often emerged that behind the conflict there was an interest. The interest somehow could be happened in short, medium and long terms. For whatsoever association, there were two main SMU groups namely those who have an authoritative domination of position and those who should obey to the authority users. If one in a quasi-group developed a jointly class awareness on a jointly interest, the organizing activity that chase the interest would emerge an interest group. Even though members of an interest group that was conflict in nature was taken from the same quasi-group, not all people in the same quasi-group should join an interest group that was conflicted in nature to chase its class interest.

An interest meant an individual desire or aspiration to focus consciously on one thing based on various backgrounds of social, economic and culture. For instance, on an animal protection: interest of children protection, interest of a healthy justice creation. Principally, the various interess that emerged could be viewed from the existence of an interest group that has various numbers. An interest conflict group gathered and changed whereby it scattered the interest in the community that become a unity to struggle in order to be a part of public policy that delivered group advantage and struggled public interest.

William Zartman (1997) said that governmental management was one of methods to manage a violence conflict in a country that needed to pay attention regarding a welfare issue or citizen satisfaction to the government in case of service, citizen expression to participate in a public region, noted competition among them and issue of resource allocation that owned by a region for their needs in regional development. Therefore, a good government was a government that was able to manage "regional conflict sources" by delivering service and welfare or satisfaction to public so that the needs of political expression, inter-public competition and the needs of treasure resource that shared profit justice could run effectively.

Furthermore, related to an effective government in relation with a regional conflict Zartman also proposed that the ongoing conflict in a state region is needed an effective governmental role in which the effective government would depends on a national consensus whereby it jointly agreed as a jointly norm. The norm was then strengthened jointly (jointly recognized) and supported by a political regime that legitimate ruling and also the existing power regime that enact them.

In understanding a conflict of interest issue in an institutional management and apparatus resources, there were several public administration theories that proposed several models, conceptual framework or different paradigms. Martin Laffin (1997) proposed three models namely: agency model, bureaucratic politics and institutionalism. Agency model viewed the relation between political institution and bureaucracy as a conflict of interest in which bureaucracy party was a party that is mastering the information. Consequently, the information flow became asymmetric. This fact became a source of bureaucracy bargaining power during the interaction with a political institution. On the other hand, a political institution had an authority of bureaucracy agents and their incentive pattern. The meeting point between these two power sources was a phenomenon that became an agency model as a 
main discussion in understanding a political institution interaction versus bureaucracy.

The second model, the bureaucratic politics viewed relationship between political institution and bureaucracy as inter-individual bargaining in which the attitude was determined by the attendance of bureaucratic affiliation and participants who attend in the interaction. Meanwhile, the effectiveness of political strategy was much determined by controlling resources and a persuasive ability level of each actor in the process of interaction. Lastly, the third model, institutionalism interpreted actor behavioral patterns that involved in the interaction process in which it comes from a historical process and specific institution. The basic assumption of this model as social reality was a social construction and the organization that played a vital role in the reconstruction process of the social reality.

\subsection{Concepts of Advocacy Coalition Framework}

The theory that was used in the analysis of conflict of interest in this study was Susan L Carpenter (1988) in her book "Managing Public Dispute". Public dispute or public conflict showed the healthy social dynamics. This phenomenon was emerged by the various factors that all needed to be noted contextually and carefully. The conflicts could be understood as a productive or destructive element if able to create an institutional correction as well as a positive output. On the other hand, conflict could also yield a long bad effect unless it could be solved proportionally and immediately. In general, public dispute or conflict indicated a democratization in which avocation towards rights, obligations and roles of politics have been addressed. An authority that was materialized in a policy process face the critics and the resistance.

Therefore, the understanding towards public dispute needed to be positioned in seizure framework and influenced the related policy processes. The disputes on public issues emerged in various sizes and forms. Generally, it happened between community and policy makers, among organization members as well as public and existed organizations. A number of conflicts could float to a confrontation that harm a bad development quickly. The framework analysis used in this study was related to the policy of Sabatier and Jenkins theory in which a policy process acts as a competition from a number of actors who advocated or struggled the faith on policy issues and its solutions. This competition occurred in a policy sub-system that was defined as a number of actors who actively paid attention on an issue and attempted to influence the related public policy continuously. Likewise, from the competition process that changes the policies among the existing groups, ACF approach also keeps formulating the alternative path of policy avocation. The method that used was a consensus through a negotiation process in order to achieve an agreement.

\section{Discussion}

\subsection{Institutional Management}

The implementation of an extension that occurred in Indonesia constitutionally and public demand was to deliver an equal service and welfare in each extended region. In the occurring extension, the important aspect in institutional management was a management for a new autonomy region and the importance of the roles in order to work suitable with vision, 
mission and institutional main tasks namely extension work procedures and management in implementing a good governance so that the regional expansion could run well, advanced and strong.

In the work mechanism of regional expansion and the implementation of regional government run by regional officials was not separable from work procedures according to the applied regulations. The work procedures in this context was related to an extension process of Pangandaran Regency (see Appendix 2). In the extension process, obviously only formally i.e. refer to Regulation Number 23/2004 and Governmental Regulation No 78 of 2007 namely indicator of score survey 350 out of population indicator of 95 , indicator value of economic ability 85, indicator value of economic potential 90 and indicator value of financial ability 80 with recommendation of Pangandaran Regency to be extended. The regulations have not been a strong principle of an extended region to be an advanced regency due to disavow institutional aspects and regional apparatus. In the implementation, the extension of Pangandaran Regency is more emphasized to the elite and public interest. This was due to the regulations in the extension was very weak and emphasizing a formal regulation only.

The effects of a weak and formal extended regulation resulted the implementation of government in Pangandaran Regency had nut run well, or even far from autonomy principles of region among others such as: (1) the government of Pangandaran Regency in the initial of government focused on personnel transfer and regional apparatus staffing from the capital Regency to Pangandaran Regency; (2) organizational structure of Pangandaran Regency Government had not wholly optimized services to the public and needed an SOPD management maximally; (3) there is no synergy of license service or other public services; 4) in the composing of KUA PPAS of 2014 there was delay due to SOPD forming and position staffing in July 2013 and the amount of budget accepted in 2014 was not known; 5) the limited office equipment in Regional Secretariat, Regional Office and Regional Technical Institution; 6) The program and Activity Composing and also Budget Activity Planning had difficulties and obstacles; 7) the weakness of information system due to not maximally utilized the information technology whereby that one established a networking; 8) accountability system was not implemented whereby it increased regional authority misused that cause inefficiency, leakage/corruption, collusion and nepotism that harm the regions 9) trends of Regent Position are less communication with the public, especially Pangandaran Presidium that triggered the conflict of interest.

\subsection{Placement of Regional Apparatus}

As the attempts to strengthen the regional expansion in Pangandaran Regency to be an autonomy region, the placement of regional apparatus should be conducted to improve regional performance. The effort of regional apparatus placement was conducted several aspects that consisted of regional apparatus educational level, recruitment, promotion, remuneration and work discipline. In the implementation and regional apparatus, the educational level in the Government of Pangandaran Regency was dominated by bachelor degrees and college scholars in all levels and also Diploma and Senior High School 
educational level. Hence, the educational facet had not fulfilled feasibility as an autonomy region. This issue really affects the performance and work ethos in the Government of Pangandaran Regency. Whereas, data showed that the development of apparatus of Pangandaran Regency is very limited both in budget and activities to strengthen the regional apparatus such as education and training.

For the recruitment process, the officials of Pangandaran Regency came from capital regency (Ciamis Regency) or Pangandaran district of origins. The selection process was only conducted in a simple way namely by an interview and willingness to transfer to the new regency of Pangandaran. In the recruitment process, there was happened dissatisfaction and problems among officials, chief and capital Regency. The solution of the problems could be overcome by the efforts to deliver explanation if Pangandaran Regency conducts the approach to the employees with new hope of Pangandaran as a region that wants to be advanced and welfare.

Meanwhile, since the beginning the extended promotion for echelon was conducted jointly into a structural position. In addition, the employee placement rightly and exactly based on the efforts to motivate employees to get satisfaction from the jobs. The employee promotion in a specific position could be a promotion for employees related if the position that is managed currently had a bigger level, more responsibility and more authority than the previous position. Otherwise, it could be a demotion if the position had a lower level, less responsibility and less authority than the previous position. The problem in the promotion was also due to the capital Regency (Ciamis Regency) sent the related officers were regarded as less professional and not suitable with the applied regulation.

The remuneration policy in Pangandaran regency had not been materialized due to the budget availability and also the concentration to bureaucracy management that was imperfect. To materialize a good governance in Pangandaran Regency properly is by violating discipline regulation for officers as well as ordinary employees should be enforced. The further importance of work discipline for apparatus of Pangandaran Regency was an accuracy to implement the task and service to the public. Hence, the policy of new cultural work discipline in the regional expansion would be materialized as expected to Pangandaran Regency expansion.

The determinant factor of the policy of regional apparatus resources placement in Pangandaran Regency was education and feasible budget availability. The limits very influence the performance and the quality of regional apparatus and bureaucrats to work maximally and professionally. Pangandaran Regency as a new autonomy region can be more advanced than other regions if it strengthened by human resources and budget in improving a bureaucracy role. The limits of education and budget also influenced the position of promotion process, regional apparatus recruitment, remuneration, and work discipline. Generally, the placement of regional apparatus resources in regional expansion of Pangandaran Regency had not been optimal due to the limited human resources and problems if local elite interest and also bureaucracy officials emerged in determination, placement process in each SKPD, recruitment process and the transfer from capital regency (Ciamis) to 
the new regency of Pangandaran.

\subsection{Conflict of Interest in Managing Institution}

In the dynamic of regional expansion as a new autonomy institution, the regional institutional management could emerge an institutional conflict. The conflict that emerged related to the interest of post-regional institutional determination to be a new autonomy region such as conflict of interest in composing and determining institutional number, institutional main task formulation, bureaucracy structure management and SOPD management that occurred in Pangandaran Regency. The problems occurred due to a readiness to be an autonomy region or extended region that was less ready politically and technically. Political tolerance was based on the regulations and commitment to regional advance instead of individual effort, group and instant interests.

A conflict of interest was a situation of a personal interest that has a difference with an organizational interest, however, the existence often adheres as well as join with an organizational interest where they are incorporated and also taking advantages from policy and management that running within. The weakness of a public staffing system in Indonesia was often began by a conflict of interest and this was occurred in almost all functions of human resources. Recruitment process, placement, promotion, mutation, development and evaluation often experienced bias due to those were contaminated by a conflict of interest.

A process of regional institutional management in regional expansion of Pangandaran Regency was not separable from a conflict of interest. Conflict of interest occurred in a strategic position as well as a strengthening effort both from an institutional facet, regional potentials and human resources that was existed in Pangandaran Regency with public figures who were less satisfied from the triggered conflicts in managing the expansion of Pangandaran Regency. For instance, an institutional regulation made by the government of Pangandaran Regency that was regarded double such as Regent Regulation Number 2 of 2013 and Number 3 of 2014 on institutional main task, Work Order and Regional Apparatus Organization, problems of Regent performance, SPOD determination and district number determination from 14 into 10 districts and also determination of Pangandaran capital.

For the implementation, the actors in regional institutional management that triggered a conflict of interest was dissatisfaction of Pangandaran extension presidium, NGO's, public figures, and bureaucracy elites. This was due to the perception difference, miscommunication and also regent roles in management and implementation of Regional Government was still regarded as less sufficient. In addition, there is also the determination of personnel who occupy the position that full of interest from bureaucracy elites, political parties and regional elites.

\subsection{Conflict of Interest in the Placement of Apparatus Resources}

When the implementation of expansion became an autonomy region, Pangandaran Regency's interests and conflicts occurred during the determination of regional apparatus resources. The conflicts that occurred were related to the determination and placement of strategic position in bureaucracy of government of Pangandaran Regency that started since the forming process 
of new region and formally became new regency. Conflict of interest on regional apparatus placement were among others as stated below:

1. In the process of real suggestion of Regent position that has been proposed, there were emerged the various interests, conflicts and also various organizations, groups and elites. They were political parties, presidium's extension and bureaucracy. The dispute that occurred was the people who asked the presidium's extension as a struggle place of Pangandaran extension to participate in determining the officials and the condition in Pangandaran after became the new region.

2. The determination process of Regional Secretary of Pangandaran Regency was not separable from a seizure interest. This was proven almost 9 (nine) months from the status of Regional Secretary vacant. The vacant occurred on the interest between Regent Official and Presidium for the placement of Regional Secretary placement.

3. The determination process of The Chief's office and regional institution of Pangandaran Regency at which there happened an opinion difference between Regent Official and Extension Presidium. The extension presidium was proposed nine offices, while Regent Official was proposed 7 offices and 4 boards that worked suitably with institutional main tasks and processes respectively.

4. In the implementation placement of employees, Pangandaran Regency got employees' devolution from the capital regency to be the personnel in the new Autonomy Regional Government. In the placement process, the civil servants (PNS) moved to Pangandaran Regency at which there happened problems and conflict of interest. Conflict of interest among civil servants from capital Regency (Ciamis) were not willing to be moved to the government of Pangandaran Regency and also problem conflict of districts of origin to occupy strategic position and employee recruitment from official relative's element.

\subsection{Conflict Resolution}

In the conflict resolution, the interest of institutional management and apparatus resource placement were explained below:

a) The establishment of a routine jointly forum among Regent, Presidium Council and the placement of human resources as the attempt to discuss the regional plans and programs.

b) The Regent that accommodated the proposal of Presidium Council and would appoint the appropriate officials and fulfilled the requirements and districts of origin.

c) The improvement of regional performance and the improvement of cooperation with the related parties in order to avoid misunderstanding that conducted by the regional government.

d) The optimization of the more aspirated regional institutional roles.

e) The establishment of jointly team among Presidium Council, Public Figures and 
Regional Government.

\section{Conclusion}

The era of decentralization, regional autonomy and regional expansion demands in Indonesia should be based on the institutional aspect in determining the regional expansion to work in regional advance according to expansion objective namely: improving human resources, improving public services, welfare and equality development in the region. In this case, it was policy of regional apparatus management that should be adjusted with management in institutional level, at which it was based on competence, work's discipline, remuneration, promotion and recruitment whereby it was based on assessment, test and precise feasibility. The proper management of regional apparatus resources were expected to be able to deliver the answer and explanation on the framework of regional expansion of performance improvement. Moreover, the extended regions should be strong, advanced and optimal based on the extension objectives.

Conflict of interest in the management of institution and position placement in the regional expansion in this case of conflict of interest related in the efforts of institution to conduct the improvement and the empowerment of regional apparatus for the regional expansion. The governmental bureaucracy was an institution that is able to deliver the political roles in resolving conflicts that emerged among people and a group of people. The relationship between political institution and bureaucracy as conflict of interest in which the bureaucracy party was a party that mastering information. Consequently, the information flow became asymmetric. These facts were the sources of bureaucracy bargaining power when interacting with a political institution. If conflict of interest in the management of regional apparatus resources would strengthen the institution, it could be handled well suitable with the regulations by using a comprehensive approach so that the conflicts that occurred in the management of regional apparatus resources in the regional expansion would be the best solution that resulted the discontinuity in other regional problems.

\section{References}

Cheema, S., \&Dennis, R. (1983). Decentralization and Development. Beverly, CA: Sage Publications.

Daniel, J. B. (1995). Performance Measurement and Management in Bouckeart, K.and Verschuere.

Elazar, D. J. (1995). Federalism, in Afan Gafar, et al., Ed. II, 1995. Regional Autonomy within the Unitary State. Yogyakarta: Pustaka Pelajar.

Fahmi, S. (2009). Law of Regional Autonomy. Yogyakarta: Total Media.

Farazmand, A. (2001).Handbook af Comperative and Development Public Administration $\left(2^{\text {nd }}\right.$ Ed.). Revised and Expanded, Marcel Dekker, Inc, New York Basel.

Ferrazzi, G. (2007). International Experiences in Territorial Reform-Implications for Indonesia, Jakarta USAID-DRSP, January p. 7. 
Fitriani. (2005). Unity in Diversity? The Creation of New Local Governments. in A

Decentralizing of Indonesian Economic Studies, $41(1)$. https://doi.org/10.1080/00074910500072690

Grindlle, M. S. (1997). Getting Good Government: Capacity Building in The Public Sector of Developing Countries. Boston, MA: Harvard Institute for International Development.

Keban, T. (2000). Basic Concept of Capacity Building Program. Jakarta: National Development Planning Magazine.

Kosworo, E. (2001). Regional Autonomy for Democracy and People's Independence. Jakarta: Pariba Foundation.

Martin, L. (1997). Understanding Minister-Bureaucrat Relation: Applying Multi-Theoretic Approaches in Public Management. Australian Journal of Public Administration, 56(1).

Prasojo, E. (2009). Second Reform, Continuing Reformation Reform. Jakarta: Salemba Humanika.

Ratnawati, T. (2010). Satu Dasa Warsa Expansion of the Reformation Era: Failure of Regional Autonomy. LIPI Journal, 21, 2010.

Smart, M. S., \& Smart, R. C. (1972). Children Development and Relationship. New York: The Mac Millan Co.

Smith. (1985). Decentralization The Territorial Dimension of the State. London: George Allence Un Win.

Smith. (1985). Decentralization The Terrortial Demension of The State. London: George Allence Un Win.

Surbakti, R. (1992). Understanding Political Science. Jakarta: Gramedia Widia Sarana Indonesia.

Susan, C. L., \& Kennedy, W. J. D. (1988). Managing Publik Dispute. SF: Jossey-Bass Publishers.

The Ministry of Internal Affairs. (2017). The Regional Expansion Had Referred to Regulation No.23/2004 on Regional Government (amended Regulation No32/2014). Retrieved at https://www.kemlu.go.id/en/default.aspx

Thoha, M. (2015). Government Bureaucracy and Power in Indonesia. Yogyakarta: Matapena Institute.

Tryatmoko, W. M. (2010). A Decade of Post-New Order Regions Arrangement: Problems and Solutions for Reform. International Seminar Paper XI Percik Salatiga Institute with Theme: What's up with 10 years of Regional Autonomy. 21-22 July 2010.

Webter. (1997). Personal and Institutional Factors in Capacity Building and Institutional Development, Working Paper No. 14, Maastrict, ECDPM. 


\section{Macrothink}

Journal of Public Administration and Governance

ISSN 2161-7104

2017, Vol. 7, No. 4

\section{Appendix}

Appendix 1. List of participants

\begin{tabular}{l|l|ll}
\hline No & Name & Position & Total \\
\hline 1. & Endjang Naffandy & Regent of Pangandaran & 1 \\
\hline 2. & Mahmud & Secretary of Pangandaran District & 1 \\
\hline 3. & Supratman & $\begin{array}{l}\text { Head of Presidium of Pangandaran District } \\
\text { Expansion }\end{array}$ & 1 \\
\hline 4. & Imam M. Ridwan & Parliament Member of Pangandaran & 1 \\
\hline 5. & Dedi Kurniadi & Youth Leader of Pangandaran & 1 \\
\hline 6. & Muhrodin Sisilawan & Citizen Representative of Pangandaran & 1 \\
\hline 7 & Undang Kosasih & President of Teachers' Association Of Pangandaran & 1 \\
\hline 8. & Syamsul Maarif & Journalist & 1 \\
\hline & & Total Participant & 8 \\
\hline
\end{tabular}

Appendix 2. Map of Pangandaran

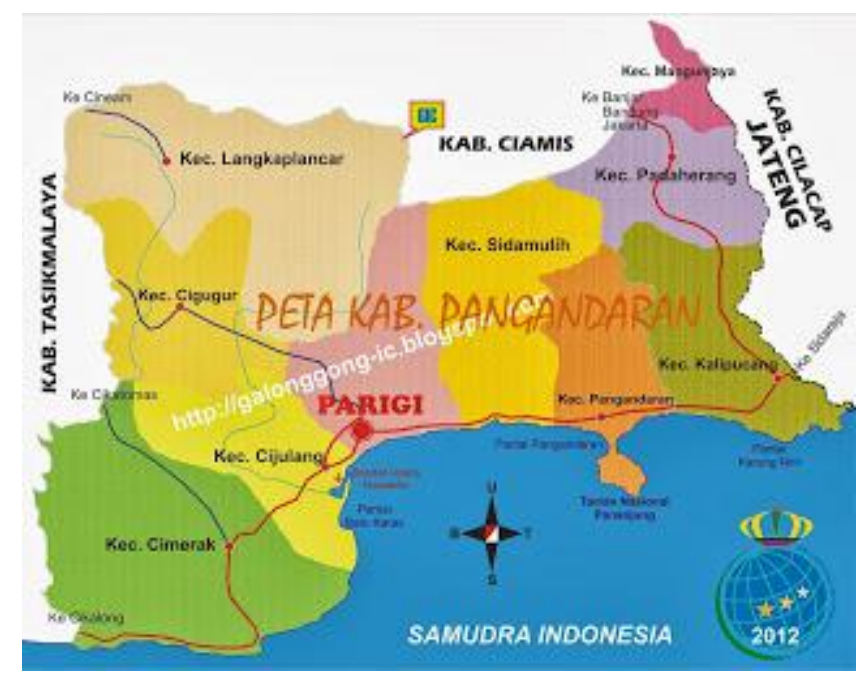

\section{Copyright Disclaimer}

Copyright for this article is retained by the author(s), with first publication rights granted to the journal.

This is an open-access article distributed under the terms and conditions of the Creative Commons Attribution license (http://creativecommons.org/licenses/by/4.0/). 